\title{
Botanical, Geographical, Herbicidal Aspects of Lemon Balm (Melissa officinalis L.)
}

\author{
Barbara Sawicka1*, Piotr Pszczółkowski ${ }^{2}$, Piotr Barbaśs $^{3}$ and \\ Bernadetta Bienia ${ }^{4}$ \\ ${ }^{1}$ Department of Plant Production Technology and Commodity Sciences, University \\ of Life Sciences, Akademicka, Lublin, Poland \\ ${ }^{2}$ Variety Assessment Experimental Station of Research Centre for Cultivar Testing, \\ Uhnin, Dębowa Kłoda, Poland \\ ${ }^{3}$ Department of Agronomy Potato, Plant Breeding and Acclimatization \\ Institute - National Research Institute, Branch Jadwisin, Serock, Poland \\ ${ }^{4}$ State Higher Vocational School in Krosno names Stanislav Pigon, Department of \\ Food Production and Safety, Dmochowskiego, Krosno, Poland \\ *Corresponding Author: Barbara Sawicka, Department of Plant Production \\ Technology and Commodity Sciences, University of Life Sciences, Akademicka, \\ Lublin, Poland.
}

\begin{abstract}
The botanical, geographical and herbicidal aspect of the species of the genus Melissa is presented. These species, especially Melissa officinalis, have been assigned a number of biological activities, such as antioxidant, antimicrobial, antitumor, antiviral, antiallergic, anti-inflammatory, and flatulence inhibiting, inhibiting germination and weed growth. The traditional pharmacological properties of lemon balm herb can be associated with the presence of bioactive phytochemicals such as terpenoids, alcohols, rosmarinic acid and phenolic antioxidants. A rich source of bioactive substances, of various Melissa species, can be considered as a promising candidate for the development of nutra-pharmaceuticals and bioherbicides. This review covers the botanical, geographical, nutritional, phytochemical and traditional medical aspects as well as the numerous biological activities of some commonly available Melissa sp. to prove their potential use in the food processing industry, the nutra-pharmaceutical and cosmetics-nutraceutical industry.

Keywords: Antioxidants; Antimicrobials; Antivirals; Antiallergics; Anti-Inflammatory; Bioherbicides; Nutra-Pharmaceuticals; Genus Melissa
\end{abstract}

\section{Introduction}

The search for new antibacterial, antiviral, anti-cancer agents from natural sources has intensified work due to the reduction of currently available therapy and the emergence of drug resistance strains. For a very long time, herbal medicines have been used to relieve the symptoms of some diseases [1]. The traditional pharmacological properties of lemon balm herb can be associated with the presence of bioactive phytochemicals such as terpenoids, alcohols, rosmarinic acid and phenolic antioxidants [2-4]. A rich source of bioactive substances from various Melissa species can be considered as a promising candidate for the development of nutra-pharmaceuticals or nutra-cosmetics [5,6]. Therefore, an attempt was made to describe and evaluate this group of plants as a potential candidate to develop new, safe, pro-ecological food preservatives, medicines and cosmetics. This material can be used in the food, pharmaceutical, cosmetics and other industries that are interested in tips on aromatic plants and essential oils.

\section{Systematics and biology}

Genus Melissa (Melissa L.) - belongs to Kingdom: Plantae, Family: Lamiaceae; Subfamily: Nepetoideae, with numerous species, of which four: Melissa axillaris (Benth.) Bakh. f., Melissa flava Benth., Melissa officinalis L. - lemon balm; Melissa yunnanensis C.Y.Wu and Y.C. Huang are recognized in the world [7,8] (Table 1). These species are found in the area from Central Asia, through Western Asia, southern Europe and northern Africa to the islands of Macaronesia [7]. Only one species grows in Europe - lemon balm M. officinalis. In nature, these plants grow in bright thickets [6].

The list of plants contains 30 scientific names of species from the genus Melissa. Of these, only 4 are accepted as species names. Another 11 scientific plant names are of an unusual rank for the genus Melissa. Species names are synonyms of adopted child names. One of the species names is registered as invalid, 2 are registered as illegal [8]. The new Melissa species found were assigned a level of trust as follows (Table 2). 


\begin{tabular}{|l|c|c|c|c|}
\hline \multicolumn{1}{|c|}{ Name } & Status & $\begin{array}{c}\text { The level } \\
\text { of trust }\end{array}$ & $\begin{array}{c}\text { Delivery } \\
\text { date }\end{array}$ & Sources \\
\hline $\begin{array}{l}\text { Melissa axil- } \\
\text { laris (Benth.) Bakh. } \\
\text { f. }\end{array}$ & Adopted & $* * *$ & 23.03 .2012 & WCSP* \\
\hline $\begin{array}{l}\text { Melissa } \times \\
\text { bolnokensis Simon. }\end{array}$ & Unresolved & $*$ & 23.03 .2012 & WCSP \\
\hline Melissa flava Benth. & Adopted & $* * *$ & 23.03 .2012 & WCSP \\
\hline $\begin{array}{l}\text { Melissa inodora } \\
\text { Hassk. }\end{array}$ & Unresolved & $*$ & 23.03 .2012 & WCSB \\
\hline $\begin{array}{l}\text { Melissa } \times \text { jahniana } \\
\text { Simon. }\end{array}$ & Unresolved & $*$ & 23.03 .2012 & WCSB \\
\hline $\begin{array}{l}\text { Melissa officinalis L. } \\
\text { Melissa rugosa_Lour. }\end{array}$ & Anresolved & $*$ & 23.03 .2012 & WCSB \\
\hline Melissa stricta_Kitt. & Unresolved & $*$ & 23.03 .2012 & WCSB \\
\hline $\begin{array}{l}\text { Melissa yunnanen- } \\
\text { sis C.Y.Wu YCHuang }\end{array}$ & Adopted & $* * *$ & 23.03 .2012 & \\
\hline
\end{tabular}

Table 1: Selected species of the genus Melissa

${ }^{*}$ Checklist of selected plant families.

\begin{tabular}{|c|c|c|c|c|c|}
\hline Specification & Adopted & Synonym* & $\begin{array}{c}\text { Not } \\
\text { placed }\end{array}$ & Unrated & Total \\
\hline $\begin{array}{c}\text { High } \\
\text { confidence*** }\end{array}$ & 4 & 19 & 0 & 0 & $\begin{array}{c}23 \\
(77 \%)\end{array}$ \\
\hline Average trust** & 0 & 0 & 0 & 0 & $0(0 \%)$ \\
\hline $\begin{array}{c}\text { Low } \\
\text { confidence* }\end{array}$ & 0 & 2 & 0 & 5 & $\begin{array}{c}7 \\
(23 \%)\end{array}$ \\
\hline
\end{tabular}

Table 2: Level of trust in found species of the genus Melissa.

*: Synonym - an alternative name that has been used to refer to the species (or subspecies, variety or form) but whose plant list does not consider to be the name currently accepted. The decision to assign a synonym status to a name record is based on a taxonomic opinion registered in the cited data source (selected using an automatic rule-based approach, according to which the list of plants was created)

Synonymy can be obtained directly from the source data (showing identical data as the source data) or can be obtained indirectly using automatic decision rules [8]. Unresolved names are those that cannot yet be assigned the status "Accepted" or "Synonym". Unresolved names are divided into two subclasses: Invaluable names for which there is no evidence in any of the data sources that the status of this name has been assessed by the data owners. None noted that he was either "accepted" or "synonymous." All names are presumably accepted until they are shown to be synonymous. Unplaced names for which the data source providing this record positively indicates that data owners tried to resolve their status and were not able to request that they be placed either as a synonym or as the accepted name of a new species. This happens when the name has insufficient description and no herbarium specimens are known, or when one or more nomenclature acts are required. The record status marked with “*” is intended to indicate that it originates from the procedures used to create the Plant List and the original name status (registered in the source database) is indicated on the details page of that name. For each name with the status "Unresolved," the list of plants is intended to ensure that the IPNI identifier (linking the record name to the International Plant Names Index which will provide full original publication details for that name [9]. Unresolved names are generally designated as the entry "Low trust." In turn, "incorrect" and "illegal" names mean that some names from the Plant List have been registered by their data sets that are to be published incorrectly or illegally, contrary to the principles of the International Code of Botanical Nomenclature. Levels of trust for each record, the name 'Plant List' indicates confidence that the record status of the name is correct. Confidence assessments are primarily based on the nature and taxonomic integrity of the source data. A high level of trust is applied to the status of name records from taxa data sets omics, which treat the entire discussed taxonomic group in global terms and have been subject to mutual verification (e.g. ILDIS, WCSP) [10]. The average confidence level was applied to the status of name records from national as well as regional databases by means of an automated rule-based process that reflected the challenges of eliminating taxonomic differences between different datasets of names of the same species for different geographical areas. Regional datasets used as sources for the Plant List are primarily stored in Tropicos, or taxonomic datasets that treat the entire taxonomic group globally, but which have not yet been peer reviewed. The low level of trust applies to the status of name records from any participating datasets that have been saved as unresolved in these sets. To records from nomenclature resources, such as IPNI, that do not provide an opinion on the status of the species name and which have been assigned the status "Undecided" on the Plant List. WCSP - provides information on accepted scientific names and synonyms of selected plant families. It contains over 320,000 names and allows the user to search for all scientific names of a specific plant or areas of the world in which it grows (distribution). The data collection is based on over 16 years of cooperation of 132 specialists from 25 countries who provided data or acted as reviewers. In addition to published family checklists, the WCSP (World Review List) contains data for many other families that have either been completed and are waiting to be checked by specialists or are being compiled [9]. The list of plants also contains unpublished data that includes over 290000 additional names [11,12]. Sources of records of species names appearing in "The Plant List" in the genus Melissa are as follows (Table 3).

\section{Short historical background}

Historically, lemon balm (Melissa officinalis) has already been recognized as an herb with a lemon scent, calming, anti-gas, feverreducing, antibacterial, spasmolytic, hypotensive, memory enhancing, menstrual, thyroid associated. The plant has been used for centuries by various cultures internationally. Lemon balm was used because of its sedative properties, and folk medicine in Portugal and Cuba attributed its anti-cancer properties [9]. Lemon balm has been assigned to the FDA's Generally Recognized List of Safe Species (GRAS) in the United States [13]. Herbs and spices have been used since ancient times to improve the sensory properties of food, acting as preservatives and for their nutritional and healthy prop- 


\begin{tabular}{|l|c|c|c|c|c|c|c|}
\hline Source & Adopted & Synonym & $\begin{array}{c}\text { Not } \\
\text { placed }\end{array}$ & Unrated & $\begin{array}{c}\text { Badly } \\
\text { used }\end{array}$ & \multicolumn{2}{|c|}{ Total } \\
\hline WCSP & 4 & 21 & 0 & 5 & 0 & 30 & $(100 \%)$ \\
\hline
\end{tabular}

Table 3: Specification of record sources. Source: WCSP.

erties. Herbs and spices are widely recognized as a safe raw material (GRAS) and are excellent substitutes for chemical additives. In turn, the oils from these plants are mixtures of volatile compounds obtained mainly by steam distillation from medicinal products and aromatic plants [13]. They are an alternative to synthetic additives for the food industry and have importance as a potential source of natural food preservatives due to growing interest in the development of safe, effective and natural food preservation. Genus Melissa, f. Lamiaceae is one of the most important in the production of essential oils with antioxidant and antimicrobial properties. You can use essential oils with antimicrobial and antioxidant properties that increase the shelf life of food and this is a promising technology. Essential oils of the Lamiaceae family, such as rosemary, thyme and sage, have been extensively studied for their use as food preservatives. New applications of essential oils in food, but also in cosmetics and pharmacy shows the latest trends in the use of these oils from aromatic plants as antimicrobials and antioxidants in food, as well as their biological activity, future potential and challenges. There are no serious side effects, although long-term studies are limited [4,13-16]. Species of the genus Melissa are also important plants resistant to ozone stress and salt stress [17-23].

\section{Biological activities}

The medicinal value of the species of the genus Melissa lies in the contained in them some chemical substances that have a specific physiological effect on the human body. The most important of these bioactive plant components are: alkaloids, tannins, flavonoids, saponins and phenolic compounds $[6,14,15,24]$. The variety of these bioactive molecules makes them a rich source of various types of potential drugs $[16,25]$. The essential oil content in lemon balm ranged from $0.02 \%$ to $0.30 \%$, which is quite low compared with other members of the Lamiaceae family. 8-cineole [22].

The antibacterial activity of essential oils has been widely reported by Dastmalchi., et al. [14], Meftahizade., et al. [25], Verma., et al. [15], Nieto [16], Abdel-Naime., et al. [6] and Chidi., et al [22]. EOs are complex mixtures of bioactive compounds, phytochemicals such as monoterpenes, sesquiterpenes, terpenoids, alcohols, aldehydes, ketones, phenolics, esters, and other complex aromatic and aliphatic compounds. These phytochemicals possess antibacterial, antifungal, anti-parasitic, and antiviral properties [6,16,21,22,26]. The plant phenolics, especially rosmarinic acid, are considered to contribute to the therapeutic potential of M. officinalis. The different biological effects of EOs are due to the concentration and proportion of their chemical constituents [27]. For example, EOs with higher concentrations of terpenoids exhibit higher antifungal activity compared with EOs rich in monoterpenes and sesquiterpenes $[14,22,28]$. E0s rich in thymol and carvacrol show higher membrane-damaging activities in bacteria than those less rich in phenolics. These authors reported that phenolic compounds present in essential oils, for example, carvacrol, eugenol, and thymol (from various plant origins), are active against many microorganisms [28]. They show different activities against Gram-negative and Gram-positive bacteria, mainly due to the position of the hydroxyl group in the phenolic structure of the terpenes $[6,21,29]$. The main mechanism of antibacterial activity is the denaturation of proteins. An increase in the antibacterial activity of terpenoids depends on the type of alkyl substituent incorporated in a non-phenolic cycle. The presence of a carbonyl function in the terpenoids' chemical structure also increases the antibacterial properties. Another aspect which influences the bioactivity of essential oils is their stereochemistry and the introduction of a double bond which increases the activity against Gram-negative bacteria $[6,14,16,22,25]$. The mechanisms of antimicrobial action identified in the EOs are the inhibition of microorganisms' growth (food safety) and the control of natural spoilage processes (food preservation) [14,22].

\section{Synonyms/shared names/related substances}

Balsam, balsam mint, bee balm, blue balsam, Citra, citronellae, citronmelisse, balsam, medicine for everything, down plant, English balsam, citronellae leaves, foil Melissae citratae, garden balm, gastrovegetalin, hjertensfryd, honey plant, pneipp Labiatae/ Lamiaceae (family), lemon balm, lomaherpan, Melissa, houseleek, beekeeper, Melissa officinalis L., Melissae, Melissae folium, Melisse (German and French), melissenblatt, melissengeist, sweet balsam, sweet mary, toronjil (Spanish), valverde boutons de fievre crème are synonyms for common names of the same species [30,31].

Naming history. In Greek mythology, Melissa was named by one of the nymphs who disturbed Zeus with her love so much that he impatiently turned her into a bee. When she died, a bee-growing plant grew out of a bewitching smell, luring all insects to itself. Another version of the myth says that Melisa taught people to collect honey, and to make it aromatic, planted a lemon fragrance herb called beehive, called melissophyllon - a honey leaf. It was used in Greek medicine 2,000 years ago. She was called "joy for the heart," the Assessment Report [30] and Paracelsus called her "the elixir of life," believing that it could completely restore a weakened human strength. Melissa refers to honey or the honeybee because the plant is so attractive to bees, and officinalis means a plant that is officially used in medicine. The Greeks called it "melisophyllon" with "meliso" meaning "bee" and "phyllon", denoting "leaf". The Romans referred to the plant as "apiastrum" from "apias", to mean simply "bee". Sixteenth-century gardeners rubbed the leaves on beehives in order to promote the production of honey $[9,15]$. In ancient times, lemon balm infusion was eagerly bathed to give the body a nice smell, flavored its leaves with wine, and rubbed places stung by bees and wasps. The herb was eagerly grown in monastery gardens, and monks mass-produced wine and spirit tinctures from it. Lemon balm was recommended for diseases of the heart, stomach, head, eyes and uterus. In the $17^{\text {th }}$ century, the "Carmelite soul" was famous - spicy lemon balm vodka, secretly produced by Parisian Carmelites. It was believed that it would help everything - from bad 
charms, migraines, gout, runny nose, abdominal pain to hysteria, angina, rickets, palpitations and restoring youth $[9,14,15]$.

\section{Geographical origin}

Plant species of the genus Melissa grow wild in North Africa (Morocco, Tunisia, Madeira, Canary Islands), Southern Europe and Asia (West and Central Asia, Caucasus, Pakistan), they also spread outside these areas. Currently, the most popular species - Melissa officinalis is known and cultivated around the world [13,15,18,31]. Aromatic plants are rich in essential oils and occur mainly in the Mediterranean region, where the production of such oils is a profitable source of ecological and economic development [16,32]. Melissa officinalis L. is indigenous of Southern Europe, Mediterranean region, Western Asia and North Africa. This species is now cultivated worldwide. In India lemon balm is cultivated in the Kashmir, Uttarakhand and some part of South India. There are two subspecies: Melissa officinalis subsp. Melissa officinalis, the common cultivated lemon balm; and Melissa officinalis subsp. altissima, naturalized in New Zealand and known as bush balm. Although Melissa officinalis subsp. officinalis is known for its lemon fragrance [15,33].

\section{Herbicidal potential}

The continuous use of synthetic herbicides to control weeds, in addition to their high efficiency, selectivity and inexpensive cost of production, has raised and continues to raise concerns on their potential impact on health and the environment [34] and the development of herbicide resistance among various weed species [3537]. Natural compounds with practical application as biological control agents are increasingly used in agriculture [35,36,38,39]. There have been numerous reports of essential oils from aromatic plants that have herbicidal effects on seeds and their germination [10,40-42]. It has been shown, among others, that essential oils of various aromatic plants, such as: Carum carvi L. (Apiaceae), Lavandula spp., Mentha spicata L., Ocimum basilicum L., Origanum vulgare L., Thymbra spicata L., Melissa officinalis L. (Lamiaceae) and other members of the Lamiaceae family inhibit seed germination and/or root extension of various weed species [36,40-46]. Lemon balm (Melissa officinalis L.) - a plant originating in southern Europe and the Mediterranean region is used in medicine, food, perfumery and cosmetics $[38,47,48]$. Furthermore, it has been established that M. officinalis essential oil is one of the four most active oils against the germination and root elongation of Raphanus sativus $\mathrm{L}$. $[10,48]$. Gitsopoulos., et al. [37] studied the herbicidal effect of the essential oils of Melissa officinalis L. and Satureya hortensis on the germination and root length of two monocotyledonous weed species (Lollium rigidum L. and Phalaris brachystachys L.) in laboratory conditions. Carvacrol and citral were their main constituents of essential oils, respectively [49,50]. The essential oil from Melissa officinalis showed a higher inhibitory effect on the germination and root length of L. rigidum and Ph. brachystachys. Also, phytotoxic effects were more pronounced in these last weed species (Table 4).

In another study, Iqba., et al. [51] proved the bio-herbicidal potential of acetone extract obtained from 30-day shoots of lemon balm (Melissa officinalis). The growth inhibiting compound was

\begin{tabular}{|l|c|c|c|c|}
\hline \multirow{2}{*}{ Essential oil } & \multicolumn{3}{|c|}{ Phalaris brachystachis } & \multicolumn{2}{c|}{ Lollium rigidum } \\
\cline { 2 - 5 } & \multicolumn{4}{|c|}{$\%$ of control } \\
\hline Satureja hortensis & $54 \mathrm{a}$ & $47 \mathrm{a}$ & $82 \mathrm{a}$ & $38 \mathrm{a}$ \\
\hline Melissa officinalis & $47 \mathrm{a}$ & $35 \mathrm{~b}$ & $72 \mathrm{~b}$ & $41 \mathrm{a}$ \\
\hline Significant at & $\mathrm{ns}$ & $\mathrm{p}<0.001^{* *}$ & $\mathrm{p}<0.05^{* *}$ & Ns \\
\hline
\end{tabular}

Table 4: The influence of essential oil of Melissa officinalis and Satureja hortensis on germination and root length Lollium rigidum and reed canary brachystachis (Phalaris brachystachis).

Means within each column followed by the same letter are not significantly different at $\mathrm{p}=5 \%$ level of Significance, ns - Not Significant.

Source: Gitsopoulos., et al. [37]

obtained using silica in gel column chromatography. Their study with an extract concentration of $0.3 \mathrm{mg} \mathrm{ml} / \mathrm{l}$, it shows the highest bioherbicidal effect on weeds [52-55].

\section{Conclusion}

Various applications of lemon balm (Melissa officinalis) extracts as raw materials for the production of medicines, cosmetics and biopesticides are well confirmed. Therefore, in order to increase effectiveness, there may be a need to introduce some biotechnology techniques that they can improve the effectiveness of these plant extracts through genetic engineering. This will significantly improve the performance of numerous metabolites containing biologically active ingredients in established plants showing increased biological activity against diseases and weeds. There is also a need to establish a policy that will support the use of home biopesticides because of their innumerable benefits compared to synthetic herbicides that threaten human health. That is why some beneficial aspects of lemon balm extracts that are easily adaptable, and which are balanced and environmentally friendly as well as their durability and stability in nature are not threatened.

\section{Bibliography}

1. Brendler T., et al. "Lemon Balm (Melissa officinalis L.). An Evidence-Based Systematic Review". Journal of Herbal Pharmacotherapy 5.4 (2005): 71-114.

2. Osakabe N., et al. "Rosmarinic Acid, a Major Polyphenolic Component of Perilla frutescens, Reduces Lipopolysaccharide (LPS)-Induced Liver Injury in d-Galactosamine (d-GalN) Sensitized Mice". Free Radical Biology and Medicine 33.6 (2002): 798-806.

3. Reddy AR., et al. "Drought-induced responses of photosynthesis and antioxidant metabolism in higher plants". Journal of Plant Physiology 161.11 (2004): 1189-1202.

4. Popova A., et al. "Melissa officinalis L.- GC Profile and Antioxidant Activity". International Journal of Pharmacognosy and Phytochemical Research 8.4 (2016): 634-638.

5. Acevedo D., et al. "Composición Química del Aceite Esencial de las Hojas de Toronjil (Melissa officinalis L.) Composición Química del Aceite Esencial de las Hojas de Toronjil (Melissa officinalis L.)". Información Tecnológica 24.4 (2013): 49. 
6. Abdel-Naime WA., et al. "Antibacterial, antifungal and GC - MS studies by Melissa officinalis". South African Journal of Botany 124 (2019): 228-234.

7. Taiwo AE., et al. "Anxiolytic and antidepressant-like effects of Melissa officinalis (lemon balm) extract in rats, Influence of administration and gender". Indian Journal of Pharmacology 44.2 (2012): 189-192.

8. Anonymous. The Plant List (2019).

9. Ulbricht C., et al. "Lemon Balm (Melissa officinalis L.): An Evidence-Based Systematic Review by the Natural Standard Research Collaboration". Journal of Herbal Pharmacotherapy 5.4 (2005).

10. Adetunji CO., et al. "Chapter 15. Homemade Preparations of Natural Biopesticides and Applications. PART III. Techniques, biotechnological and computational approach, Edited by Chukwuebuka Egbuna, Barbara Sawicka, ELSEVIER, Publisher: Academic Press (2019): 179-185.

11. Anonymous. Germplasm Resources Information Network (GRIN) (2011).

12. Anonymous. Embryo Resources Information Network (GRIN) (2019).

13. GRAS 2020. Generally recognized as secure (GRAS) (2020).

14. Dastmalchi K., et al. "Chemical composition and in vitro antioxidative activity of a lemon balm (Melissa officinalis L.) extract". LWT - Food Science and Technology 41 (2008): 391-400.

15. Verma P.P.S., et al. "Lemon balm (Melissa officinalis l.) an herbal medicinal plant with broad therapeutic uses and cultivation practices, a review". International Journal of Recent Advances in Multidisciplinary Research 2.11 (2015): 928-933.

16. Nieto G. "Biological Activities of Three Essential Oils of the Lamiaceae Family". Medicines 4 (2017): 63.

17. Sofo A., et al. "Lipoxygenase activity and proline accumulation in leaves and roots of olive trees in response to drought stress". Physiologia Plantarum 121.1 (2004): 58-65.

18. Mahajan S and Tuteja N. "Cold, salinity and drought stresses, an overview". Archives of Biochemistry and Biophysics 444.2 (2005): 139-158.

19. Pellegrini E., et al. "Ozone stress in Melissa officinalis plants assessed by photosynthetic function”. Environmental and Experimental Botany 73 (2011): 94-101.

20. Zhu JK. "Abiotic stress Signaling and responses in plants". Cell 167.2 (2016): 313-324.

21. González-Villagra J., et al. "Age-related mechanism and its relationship with secondary metabolism and abscisic acid in Aristotelia chilensis plants subjected to drought stress". Plant Physiology and Biochemistry 124 (2018): 136-145.

22. Chidi IS., et al. "In vitro comparison of the anti-bacterial activity of Cnidoscolus aconitifolius and Ocimum gratissimum Hydromethanolic Leaf Extracts". Journal of Dental and Medicical Sciences (IOSR-JDMS) 18.1 (2019): 73-80.
23. Mohammadi S., et al. "Age-dependent responses in cellular mechanisms and essential oil production in sweet Ferula assafoetida under prolonged drought stress". Journal of Plant Interactions 14.1 (2019): 324-333.

24. Pietta G. "Flavonoids as Antioxidants". Journal of Natural Products 63.7 (2000): 1035-1042.

25. Meftahizade H., et al. "Improved In vitro culture and micropropagation of different Melissa officinalis L. genotypes of phenolic compounds". Trends in Plant Science 2.4 (2012): 152159.

26. Vokou D., et al. "Effects on monoterpenoids, acting alone or in pairs, on seed germination and subsequent seedling growth". Journal of Chemical Ecology 29 (2003): 2281-2301.

27. Tohidi B., et al. "Essential oil composition, total phenolic, flavonoid contents, and antioxidant activity of thymus species collected from different regions of Iran". Food Chemistry 220 (2017): 153-161.

28. Figueiredo AC., et al. "Factors affecting secondary metabolite production in plants, volatile components and essential oils". Flavour and Fragrance Journal 23.4 (2008): 213-226.

29. Mimica-Dukic N., et al. "Antimicrobial and antioxidant activities of Melissa officinalis L. (Lamiaceae) essential oil". Journal of Agricultural and Food Chemistry 52.9 (2004): 2485-2489.

30. Assessment Report on Melissa officinalis L., folium based on Article $16 \mathrm{~d}(1)$, Article $16 \mathrm{f}$ and Article $16 \mathrm{~h}$ of Directive 2001/83/EC as amended (traditional use). 14 May 2013 EMA/HMPC/196746/2012 Committee on Herbal Medicinal Products (HMPC) (2013).

31. Filipović V and Ugrenović V. "Lemon balm Melissa officinalis L. Technology of cultivation and production cost estimate. International Scientific Meeting Sustainable agriculture and sustainability". Ed. Jonel Subić, Marko Jeločnik, Boris Kuzman, Andrei Jean Vasile. Institute of Agricultural Economics in Belgrade. Serbia, Chamber of Commerce and Industry of Serbia, Belgrade Serbia (2018): 794-810.

32. Gürbüz B., et al. "(Melissa officinalis L.) Hatlarinin Ankara Koşullarinda Herba Verimi Ve Bazi Özelliklerinin Araştirilmasi". Akdeniz Üniversitesi Ziraat Fakültesi Dergisi 21.1 (2008): 8596.

33. Zandalinas SI., et al. "Plant adaptations to the combination of drought and high temperatures". Physiologia Plantarum 162.1 (2017): 2-12.

34. Dayan FE., et al. "Managing weeds with natural products". Pesticide Outlook 10 (1999): 185-188.

35. Dayan FE., et al. "Natural products in crop protection". Bioorganic and Medicinal Chemistry 17 (2009): 4022-4034.

36. Azirak S and Karaman S. "Allelopathic effect of some essential oils and components on germination of weed species". Acta Agriculturae Scandinavica, Section B - Soil and Plant Science 58 (2008): 88-92. 
37. Gitsopoulos TK., et al. "Herbicidal effects of Satureja hortensis L. and Melissa officinalis L. essential oils on germination and root length of Lollium rigidum L. and Phalaris brachystachys $\mathrm{L}$. grass weeds". Hellenic Plant Protection Journal 6 (2013): 4954.

38. Duke SO., et al. "Chemicals from nature for weed management”. Weed Science 50 (2002): 138-151.

39. Tworkoski T. "Herbicide effects of essential oils". Weed Science 50 (2002): 425-431.

40. Vaughn ST and Spencer GF. "Volatile monoterpenes as potential parent structures for new herbicides". Weed Science 41 (1993): 114-119.

41. Dudai N., et al. "Essential oils as allelochemicals and their potential use as bioherbicides". Journal of Chemical Ecology 25 (1999): 1079-1089.

42. Dudai N., et al. "Biotransformation of constituents of essential oils by germinating wheat seed". Phytochemistry 55 (2000): 375-382.

43. Dudai N. "Potential Use of Essential Oils as Bio-Herbicides, Ecology, Physiology and Agrotechnology Aspects". In: Abstracts of Novel and Sustainable Weed Management in Arid and Semi-Arid -Ecosystems, Rehovot, Israel (2007): 34.

44. Angelini LG., et al. "Essential oils from Mediterranean Lamiaceae as weed germination inhibitors". Journal of Agriculture and Food Chemistry 51 (2003): 6158-6164.

45. Vasilakoglou I., et al. "Herbicidal potential of essential oils of oregano or marjoram (Origanum spp.) and basil (Ocimum basilicum) on Echinochloa crus-galli (L.) P. Beauv. and Chenopodium album L. weeds". Allelopathy Journal 20 (2007): 297306.

46. Argyropoulos EI., et al. "In vitro evaluation of essential oils from Mediterranean aromatic plants of the Lamiaceae for weed control in tomato and cotton crops". Allelopathy Journal 22 (2008): 69-78.

47. Tagashira M and Ohtake Y. "A new antioxidative 1,3-benzodioxole from Melissa officinalis". Planta Medica 64 (1998): 555558.

48. De Almeida LFR., et al. "Phytotoxic Activities of Mediterranean Essential Oils". Molecules 15 (2010): 4309-4323.

49. Chaimovitsh D., et al. "The relative effect of citral on mitotic microtubules in wheat roots and BY2 cells". Plant Biology 14 (2012): 354-364.

50. Sadraei H., et al. "Relaxant effect of essential oil of Melissa officinalis and citral on ratileum contractions". Phytoteraphy 74 (2003): 445-452.

51. Iqba Z., et al. "Allelopathy of buckwheat: assessment of allelopathic potential of extract of aerial parts of buckwheat and identification of fagomine and other related alkaloids as allelochemicals". Weed Biology and Management 2 (2002): 110-115.
52. Batish RD., et al. "Phytotoxicity of lemon-scented eucalypt oil and its potential use as a bioherbicide". Crop Protection 23 (2004): 1209-1214.

53. Beziĉ N., et al. "Phytochemical composition and antimicrobial activity of Satureja montana L. and Satureja cuneifolia essential oils". Acta Botanica Croatica 64 (2005): 313-322.

54. Singh HP., et al. "Allelopathic interactions and allelochemicals, new possibilities for sustainable weed management". Critical Reviews in Plant Sciences 22 (2003): 239-311.

55. Vokou D., et al. "Effects on monoterpenoids, acting alone or in pairs, on seed germination and subsequent seedling growth". Journal of Chemical Ecology 29 (2003): 2281-2301.

\section{Assets from publication with us}

- Prompt Acknowledgement after receiving the article

- Thorough Double blinded peer review

- Rapid Publication

- Issue of Publication Certificate

- High visibility of your Published work

Website: www.actascientific.com/

Submit Article: www.actascientific.com/submission.php Email us: editor@actascientific.com Contact us: +919182824667 